\title{
The Effect of WTO Membership on Service Sector Trade Liberalization
}

\section{Author(s): Chase Englund}

Source: Journal of International Logistics and Trade 2022; 20(1)

Published by: Jungseok Research Institute of International Logistics and Trade, Inha University

DOI: https://doi.org/10.24006/jilt.2022.e2

Journal of International Logistics and Trade is an official journal published by Jungseok Research Institute of International Logistics and Trade, Inha University, Korea. JILT welcomes manuscripts that advance the practice and science of logistics, trade, and other related fields.

Frequency: Quarterly (March, June, September, December)

Stable URL: https://www.ejilt.org

Jungseok Research Institute of International Logistics and Trade is a specialized academic research institute representing Inha University and Inha Foundation in Korea. The institute aims to become a representative institute in Northeast Asia in the research of logistics and trade.

Stable URL: https://jrieng.inha.ac.kr

(C) Copyright. Jungseok Research Institute of International Logistics and Trade.

This is an Open-Access article distributed under the terms of the Creative Commons Attribution NonCommercial License (http://creativecommons.org/licenses/by-nc/4.0/) which permits unrestricted noncommercial use, distribution, and reproduction in any medium, provided the original work is properly cited 



\section{ARTICLE}

\section{The Effect of WTO Membership on Service Sector Trade Liberalization}

\section{Chase Englund}

Department of Government and Politics, University of Maryland, College Park, MD 20742, USA

Received August 16, 2021
Revised October 01, 2021
Accepted October 28, 2021

*Corresponding author: Chase Englund
Department of Government and Politics,
University of Maryland, College Park, MD
20742, USA
Tel: +1-16103086941
E-mail: cenglund@umd.edu

\begin{abstract}
A large portion of labor and trade in most countries is devoted to the service sector, and thus service sector impacts are crucial to a full understanding of the effects of WTO membership. The effect of WTO membership on trade volume has been subject to debate in the past, but critically, these studies have failed to examine service sector trade specifically. Conventional wisdom would seem to suggest that WTO membership should have boosted services trade, particularly after the implementation of the General Agreement on Trade in Services (GATS) in 1995. However, the relationship has yet to be rigorously tested. Here, I use data comprising 178 countries across a span ranging from 1995 until 2015 to examine the impact that WTO membership, and specifically WTO accession, has had on service sector trade levels relative to goods trade levels after the adoption of GATS. Statistical tests yield weak evidence for any significant relationship between WTO membership and service sector trade, with some possible exceptions for states that underwent many rounds of negotiations. This exception is explored further through a comparison of the WTO accessions of China and Vietnam. However, even in these extreme cases, it is difficult to find clear evidence of service sector liberalization. Overall, the findings imply that, in almost all cases, WTO rules and accessions have underemphasized service sector trade in favor of agricultural and goods trade, generating lopsided impacts to trade efficiency.
\end{abstract}

Keywords WTO, Service sector trade, Liberalization, General Agreement on Trade in Services, Accession

\section{Introduction}

Since its formation from the General Agreement on Tariffs and Trade (GATT) in 1994, the World Trade Organization has maintained a strong program focus on goods sector trade. This begs the question, how much of an impact does the WTO have on the service sector? Interestingly, the most commonly cited literature mostly ignores this aspect of trade. While data limitations may have precluded a rigorous study of services trade in the past, data availability has now greatly improved. Particularly when examining developed economies with strong service sectors, excluding this measure gives a warped measure of trade at best, and an outright incorrect measure at worst. The service sector accounts for more than $75 \%$ of labor in the US, and 55\% of labor in China (U.S. Bureau of Labor Statistics, 2018). In 2017, service sector products accounted for more than a third of all US exports (World Bank 2019). By the WTO's own estimate, the welfare gains from service trade liberalization could exceed goods trade liberalization by several times, especially for developing countries (Hufbauer and Stephenson 2007). The WTO estimates that trade in services now accounts for over $50 \%$ of world trade from a valued-added standpoint (World Trade Organization 2019c). In this paper I explore the impact of WTO membership on trade in services, and find little evidence to support the claim that the WTO has been effective at addressing these issues, in fact finding that the organization's impact to the service sector has been negligible in all but a few cases.

This subject is increasingly important. Economists have generally acknowledged that graying populations, relatively expensive labor, and stricter environmental and safety regulations have left developed countries at a relative disadvantage in the low-skilled-labor-driven manufactured goods trade. States like China, operating with fewer of these constraints, have consistently gained market share in the trade of these goods. However, many of these economists also point to a silver lining; while free-trade organizations like the WTO may subject the vulnerable manufacturing sector to stronger competition, they also open up new markets for exports from the service sector, where relatively higher-skilled workers from developed countries generally fare better (for an updated discussion of this, Barattieri 2014). In fact, the USA has had a service sector trade surplus 
with China since it joined the WTO in 2001 (Federal Reserve Bank of St. Louis 2017). However, due to a myopic focus on the goods trade on the part of the WTO, developed countries have been less able to realize this advantage due to continued protectionism, which restricts access to large service markets such as China's. This has led to increasing political tensions surrounding trade, which now threaten to upend the last decades of trade liberalization.

This paper is laid out in three sections. In Section 2, I discuss existing literature on this topic and why the impact of WTO membership on trade in services merits further consideration, laying a theoretical foundation. Much attention has been paid to the WTO and its impact on trade, but little of it focuses specifically on the critical component of service sector trade. In Section 3, I describe the data and discuss the empirics of measuring trade growth in the service sector. In Section 4, I specify a large-n model of trade using data developed from the World Bank, covering over 178 states across twenty years. In order to increase the robustness of my findings, I also explore some potential conditioning variables on WTO membership, such as the rigor of accession. Finally, in Section 5, I explore two important service sector liberalization case studies, China and Vietnam, where the involved states were involved in many rounds of negotiation. Lastly, I lead into a discussion of implications for policy and future research.

\section{How does the World Trade Organization impact trade?}

According to mainstream political and economic theory, we should expect the WTO to facilitate increases in trade. Like all intergovernmental organizations (IGOs), the WTO exists to solve problems of cooperation and trust in an inherently anarchic international system. The organization acts as a forum for states to coordinate expectations and engage in reciprocal tariff cutting, as well as to coordinate on the reduction of trade inhibiting regulations and restrictions, known as non-tariff barriers (NTBs). The dispute settlement function acts as an enforcement mechanism for the agreements that are made. The resulting tariff and NTB reductions serve to increase import quantities in scarce-factor sectors, while increasing export quantities in abundant-factor sectors. The net trade impact to trade volume from tariff reduction should therefore always be positive (Barattieri 2014).

This relatively simple story constitutes a seemingly plausible theory, but do the data support it? This question has been examined a number of times in relation to the trade in goods, and it is generally accepted that for trade in goods, WTO membership, whether by itself or with some additional variable, is expected to have a positive effect on trade volumes. However, the question is not without dispute. In a well-known early paper on this subject, Andrew Rose argued that the WTO did not in fact increase levels of trade (Rose 2004). He examined trade levels between over 20,000 state-to-state trading dyads in a simple "gravity model" and was unable to find a statistically significant relationship between WTO membership and trade growth. Rose is somewhat vague about the theoretical reasons for this, calling his finding "a mysterious puzzle". However, this somewhat contrarian stance prompted a number of responses defending the traditional understanding. Goldstein, Rivers, and Tomz published a response where they found a strong increase in trade volume associated with WTO membership by including certain methodological changes in their replication of Rose's model (Goldstein et al. 2007). Their argument suggested that Rose's non-result was the product of these methodological errors, and reiterated the mainstream theoretical arguments of "principles of reciprocity" and "the existence of a dispute settlement mechanism" being reasons for the WTO effect.

More recent literature has taken a more nuanced approach in supporting the conception of a trade- inducing WTO. The same year that Goldstein, Rivers, and Tomz published their response article, Subramanian and Wei made an argument that the WTO facilitated growth in trade, but specified that the effect was only strongly present for states that underwent liberalization and reciprocal negotiations as part of their joining the WTO (Subramanian and Wei 2007). This approach was later refined by Todd Allee and Jamie Scalera in a 2012 paper which examined WTO membership asymmetry along several axes of accession difficulty, used as a proxy for trade liberalization (Allee and Scalera 2012). This debate is far from concluded, but recent empirical analysis seems to vindicate this event (particularly accession) driven model, but while also discounting the original, more generic membership theory (Eicher and Henn 2011).

Despite the debate and progress of this literature, one major feature has been excluded both theoretically and empirically, and that is service sector trade. Virtually all of the heretofore mentioned studies looked exclusively at merchandise trade. ${ }^{1}$ There are features of the WTO relative to service sector trade which make some of these mechanisms less plausible. For starters, the WTO did not begin regulating services trade until 1995, so any effect on services openness prior to 1995 could not have been present. Additionally, very few states have been subject to dispute cases involving services. Among the recorded cases,

${ }^{1}$ This was fairly standard at the time, as there was relatively much less data available on services trade. 
only $10 \%$ involved services trade, and many of these could be considered "hybrids" that involved a mix of goods and services. ${ }^{2}$ Therefore, for most states, a direct effect from the dispute mechanism is not measurable.

Outside of dispute cases, we can also point to some clear cases where the effect of the WTO on trade seems to differ between the goods and services sectors more generally. For example, after China joined the WTO in 2001 following an aggressively negotiated accession, their aggregate level of services trade as a percentage of gross domestic product (GDP) actually fell (World Bank 2019). Far from being an anomaly, this trend is actually the norm, occurring in other liberalizing states like Vietnam (World Bank 2019). This, together with unique features of the WTO General Agreement on Trade in Services (GATS), all suggests that services and goods trade might be subject to different outcomes despite similar WTO mandates.

Despite these important differences between service sector and goods trade, there are other reasons to suspect that these differences may not change the predicted outcome greatly. Many service sector jobs are often inherently local and not easily traded between states, therefore not responsive to tariffs rates or other barriers. However, many others (often the most productive such as banking and consulting) can be traded. Furthermore, variables typical to the gravity model such as language and distance also help account for the "human factor" inherent to the services trade (we should expect these variables to have larger coefficients for services trade, Kimura and Lee 2006). Therefore, if states commonly place barriers on these tradable service sector industries (which they do), than service sector trade should be responsive to WTO induced liberalization. If we accept the ideas posited by Allee \& Scalera and Subramanian \& Wei, states that undergo rigorous negotiation conditional to their accession to the WTO should experience a boost to trade in all industries that experienced significant liberalization as a result. In other words, there is no reason to suspect that WTO induced trade liberalization should affect the goods trade only, assuming that the WTO liberalization is targeted equally at both sectors.

In practice, accession to the WTO can be quite onerous, involving at least twenty distinct steps. Generally, the most important of these are the formation of a Working Party, which considers the application of a new applicant, and the drafting of a memorandum on the applicant's foreign trade regime. Once this memorandum is compiled, it is opened to questions from the existing member states. These questions are addressed by the applicant, oftentimes involving the making of explicit commitments to reduce barriers or take other measures. The applicant then resubmits the memorandum, or in some cases submits a revised memorandum, which is either accepted by the Working Party or returned with more questions. Inherent to this process the applicant must complete bilateral negotiations with each member of the Working Party. Any existing member of the WTO can join a Working Party (for a detailed accounting of this process, Evenett and Braga 2005).

The rigor of WTO accession can be influenced by a number of factors. The presence and number of trade experts in the country, the available budget to spend on hosting talks, and the influence of random endogenous events such as political transitions can all influence the total number of negotiating rounds. Generally speaking, accession negotiations have grown longer and more rigorous as the WTO has adopted more rules. ${ }^{3}$ However, it is also quite plausible to imagine that the rigor of negotiations is influenced by the level of existing protections in the country at the start of negotiations. This raises an interesting question: does rigorous accession measure the exogenous degree of pressure applied by the WTO, or is it a proxy for the endogenous starting level of trade protection? As will be discussed in the proceeding section, the existing data and nature of service sector trade protections makes it difficult to control for this factor in a straightforward way. However, any significant results will need to be interpreted with this issue in mind. This consideration notwithstanding, the fact remains that the WTO accession process is the primary means by which we can expect WTO-induced liberalization to occur, especially when this accession is rigorously negotiated.

For the purposes of this study, I continue under the assumption that it is plausible to say that WTO accession could positively effect service trade openness by itself. In keeping with the more recent literature, I will also test conditional arguments whereby membership must involve an accession where there was at least some degree of conditional trade liberalization, temporary or otherwise. As I will demonstrate, weaknesses in the GATS framework makes this outcome less likely. Testing a simple model of WTO membership on trade volume, and by using "accession difficulty" and several other conditionalities, I address the existing gap in this literature, which is the exclusion of services trade from previous studies that examine this subject. Additionally, I examine several case studies to examine the accession process in more detail in order to determine how and when it reduces service sector protectionism.

\footnotetext{
${ }^{2}$ The first services related dispute case is a typical example. Case DS16 mediated the "Importation, Sale and Distribution of Bananas".

${ }^{3}$ The mean number of negotiating rounds during rigorous accessions pre-1995 was 3.6, while post-1995 is was nearly a full round higher at 4.5 .
} 


\subsection{Understanding the service sector}

Since the organization was founded in 1948, WTO accession has focused almost exclusively on trade of agricultural and manufactured goods. Rules on trade in services weren't incorporated into the GATT/WTO until the Uruguay Round completed in 1994, referred to as the GATS (World Trade Organization 2019c). GATS is the first and only set of agreements on services trade and is comprised mostly of agreement around non-specific general principles (World Trade Organization 2019b). This was not entirely unintentional. The GATS was vague partly by design, as many of the states involved in the drafting were unsure of exactly what they wanted and opted for broad principles instead of specific rules. Since many services such as banking, accounting, or auditing may overlap with government functions, rules around these were considered to be sensitive. Although increased market access was a principle goal of the agreement, states were given broad interpretive powers regarding which services they actually applied these rules towards (World Trade Organization 2019c). In addition to this, developing states (the demographic from which most recent applicant states are drawn) are allowed wide flexibility on a range of GATS provisions (Mattoo and Sauv'e 2008). In sum, goods trade issues comprise 83\% of WTO founding articles and $90 \%$ of all dispute cases (World Trade Organization 2019b).

In addition to these design factors, there are other factors that present challenges to GATS, related to the nature of service sector trade protectionism itself. Service imports are more likely to face barriers arising from non-tariff measures, which can be harder to detect and eliminate than simple tariffs most frequently applied to goods imports (Dee and Ferrantino 2005). These regulatory measures are often subject to case-by-case revision and exist at multiple levels of government (as opposed to just at ports of entry). Together, the flexibility of GATS together with the more opaque nature of service sector protectionism creates a situation in which service sector liberalization efforts may be uniquely dependent on both the expertise of WTO negotiators and the applicant state's willingness to cooperate with the Working Party.

Despite these challenges, there is still reason to suspect that the GATS may have induced service sector gains for member states, particularly those states that underwent more onerous accession processes or those that made more sweeping commitments under GATS. Following the Uruguay Round of negotiations, the implementation of the GATS saw the adoption of binding rules around most types of services, including transport, finance, education, tourism, and legal services. The GATS agreement was originally conceived and lobbied for by developed states, which sought to open new markets for services exports, in which those states held a comparative advantage (Marchetti and Mavroidis 2011). Despite resistance from lesserdeveloped states, this initiative was successful in implementing a number binding commitments, covering a large segment of services by category and by revenue. High revenue sectors like financial services saw new rules to cover approximately $95 \%$ of activities as measured by revenue in banking, securities, insurance, and information services (part of the WTO's Financial Services Agreement, Kelsey 2016).

Since GATS was finished, the WTO has also continued to push for or indirectly facilitate broad liberalization in the services. Newly acceding states are required to make extensive GATS commitments, often greater than those made by original members (Kelsey 2016). Additionally, the most-favored nation framework ensures that additional bilateral or multilateral agreements outside of the GATS will still enduce WTO members to liberalize more broadly. For example, agreements such as the 2008 economic partnership agreement between the EU and a consortium of Caribbean states (Cariforum-EU EPA) required participant states to make liberalization commitments in a "benchmark" of 60-70 percent of service sub-sectors (Kelsey 2016). This benchmark concept had been widely used in other multilateral and bilateral trade negotiation efforts as well.

Consistent with the expectation that WTO membership could plausibly serve a catalyst for increasing services trade flows, I test the following primary hypothesis:

H1: States that attain WTO membership will, on average, exhibit higher levels of service trade inflows post-accession than similar states that are not members.

The effect should be most observable for service sector inflows, because most states that acceded to the WTO after 1995 were developing states that were net importers of services. In keeping with more recent literature, and the expectation that these effects should be greater in those states that committed more strongly to services trade liberalization as part of their accession, we can also generate several additional testable claims.

$\mathrm{H} 2$ : States that undergo rigorous liberalization as a condition of WTO membership will, on average, exhibit higher levels of service trade inflows post-accession than similar states that do not undergo this process.

Additional rounds of questioning is one metric used to measure the difficulty of accession, and thus additional rounds is an indicator that a negotiation was more difficult and may have required more or more significant concessions.

H3: States that undergo a higher number of rounds of questioning as a condition of WTO membership will, on average, 
exhibit higher levels of service trade inflows post-accession than similar states that do not undergo this process.

Services commitments is another metric used to measure rigor. While an additional commitment does not necessarily indicate full liberalization or even that the commitment was consistently met, it does indicate that a state was compelled to promise liberalization at least in principle.

H4: States that make more general (and specific) service sector commitments as a condition of WTO membership will, on average, exhibit higher levels of service trade inflows post-accession than similar states that make less commitments.

As discussed above, it remains empirically unclear what exactly leads to a rigorous accession, and how such a process might induce liberalization. Such that this is the case, I will use several case studies to examine the rigorous accession process more closely. As discussed, certain provisions in the GATS are vague enough to be subject to multiple interpretations. Therefore, it seems plausible that there would be variation in the effect of negotiations, as states would have some leeway in how GATS statutes are implemented. In turn, the degree of liberalization may depend at least in part on the expertise of negotiators and how the applicant state chooses to apply the provisions. I generate the following hypothesis regarding when rigorous accession is most effective. This hypothesis will be examined in Section 5.

H5: Rigorous accession that occurs in an accommodating political environment, or an environment in which Working Party negotiators hold a comparative advantage in expertise, will result in higher levels of service trade inflows post-accession than similar cases where these conditions are not met.

\section{Measuring trade in the service sector}

In order to measure services trade, I utilize a multiyear global dataset that measures trade inflows at the state level. This statelevel data is sourced from the World Bank and contains cases beginning in 1960. The data was collected by the IMF through that organization's Balance of Payments Statistics data collection program, which began in 2005. Services are defined as "intangible commodities that may be produced, transferred, and consumed at the same time".

The state-level data used to test H1 and H2 was collected from the World Bank's Development Indicators. International Organization membership data was collected from the Correlates of War data project (Nordstrom \& Warnke 2004). The data on WTO accession was obtained from an original dataset developed by Allee and Scalera (Allee and Scalera 2012), which I use to measure accession rigor, round of questioning, and number of service sector commitments. Rigorous WTO Accession is coded as 1 round or more of negotiations, maintaining the method used by Allee and Scalera.

As Figure 1 demonstrates, most service liberalization should have occurred in developing states which joined the WTO later. These are also the states which should experience the biggest comparative disadvantage in services trade. Thus, if WTO liberalization is effective, we should expect that these liberalizations should have been accompanied by positive shocks to service sector imports (SSI).

As we can see from Figures 2(a) and (b), the typical WTO accession case has not been "rigorous". A majority of states have undergone zero or few rounds of questioning, shown in Figure 2(a). However, some notable recent cases such as China saw more significant liberalization pressures. China underwent 19 separate rounds of questioning before acceptance, potentially indicating more significant pressure for liberalization. This data also contained information about specific service sector

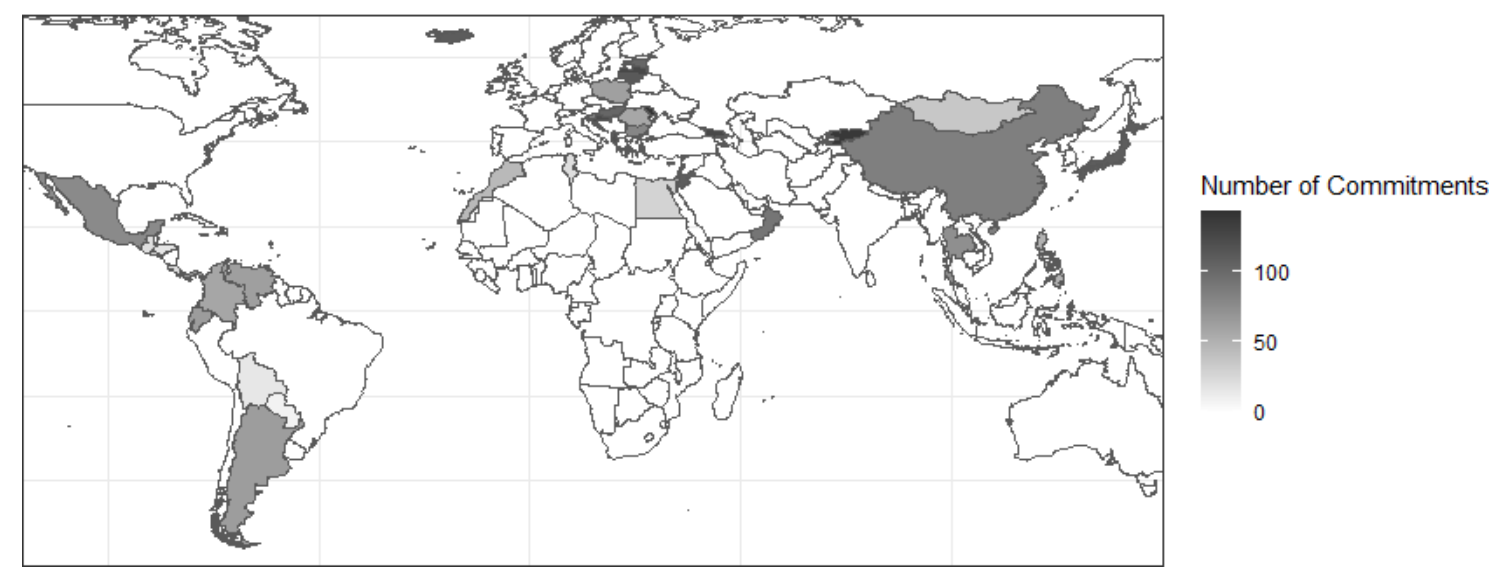

Figure 1. Services commitments by state. 


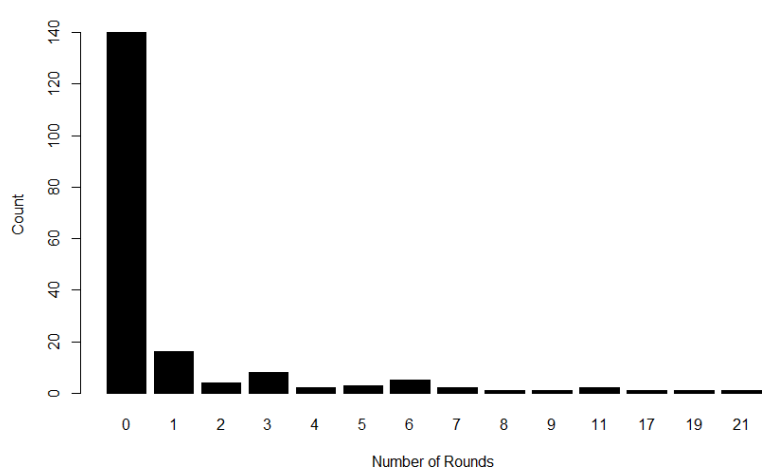

(a)

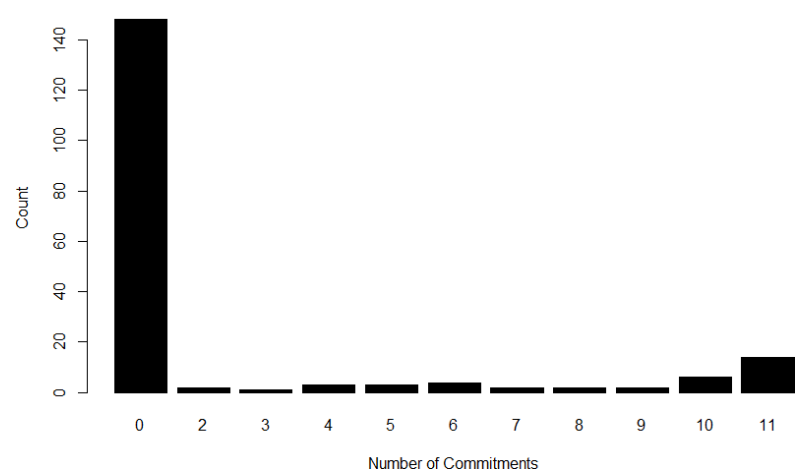

(b)

Figure 2. Accession Rigor. (a) Total rounds of questioning prior to entering the WTO, (b) Total service sector commitments prior to entering the WTO.

commitments made during accession. Specific commitments measured the actual number of specific commitments made across all sectors. General commitments measured the number of sectors in which commitments were made. Similarly to rounds of questioning, most states joined after making very few general commitments to liberalize, shown in Figure 2(b). The global average for states that made service commitments saw the mean of general commitments at 8 and the mean for specific commitments at 72 , but as we can see, this is primarily driven by a few outliers. Oftentimes, commitments and rounds of negotiation are positively correlated (for example, the highly negotiated case of China saw 9 general commitments and 85 specific commitments, slightly more than average), but this was not always the case. Especially since the measures are not trade-volume weighted, I test for all three commitment types as possible indicators of greater liberalization.

The state level data also shows a clear trend relative to the importance of the services sector as a percentage of overall trade. In the majority of the states present in the dataset, service trade has grown as a proportion of the overall economy. This reflects both the global growth in the services trade generally, as well as the increasing ease of exporting these services.

As seen in Figure 3, the period since 1960 saw strong growth in trade in the service sector. This is consistent with some of the fundamental economic trends discussed earlier, such as technology improvements which facilitated faster and more efficient cross-border communication.

As control variables, I used several standard economic variables. As discussed, there are not a large number of service sectorspecific models in the literature, but the controls used here are similar to the ones employed by Baggs et al. (2010) in their model of service sector trade. GDP growth rate should fairly consistently predict trade volume for both goods and services, as higher economic output results in more imports. State currency value is also an important factor in determining import and export levels. I used the state local currency unit (LCU) value against a weighted average of other large currencies. As the local currency becomes more valuable, imports should increase as foreign goods are relatively cheaper. I also include FDI inflows,

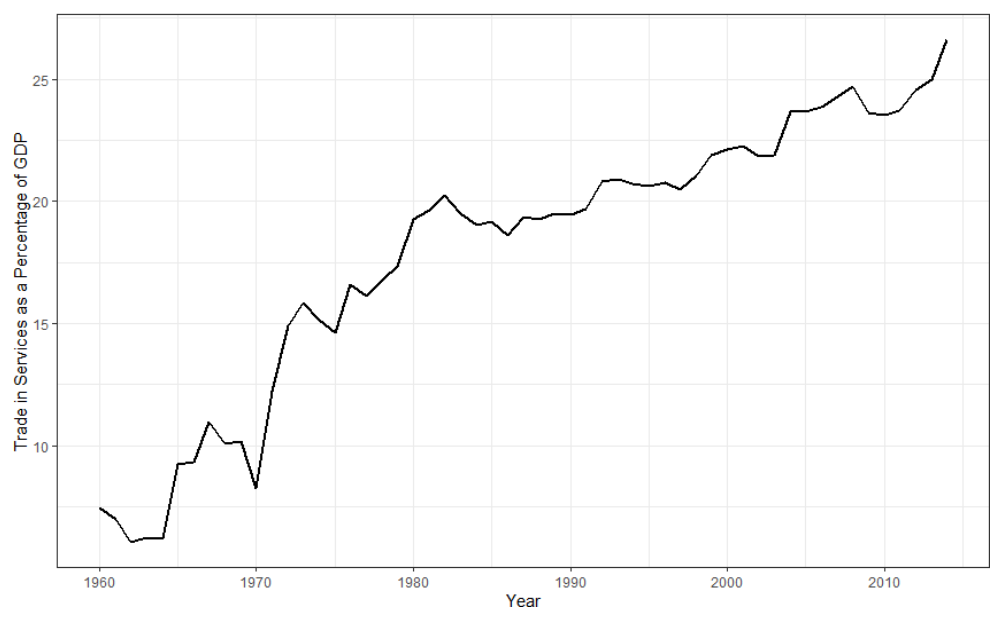

Figure 3. Share of services trade over time (global mean). 
as outside investment should predict an increase in import demand independent of GDP growth. None of these variables should covary strongly with WTO membership per se, but they provide substantive context as they are the traditional primary explanators of trade levels. I also included OECD membership, which proxies as a measure of development and therefore covaries strongly with trade openness, democracy, and service sector specialization (Wölfl 2005 or "Member States - About the OECD" for more on this).

The regression data was constructed by merging the World Bank trade data and WTO data, comprising 178 states over 55 years which results in roughly ten thousand observed cases. Restricting the data to observe the post-GATS period after 1995 reduces the number of sample cases by about two thirds. Missingness in the data for states where aggregate services import data could not be accurately collected results in a total number of 1,718 cases in the sample.

\section{Regression analysis}

My standard specification approach for all models was to use ordinary-least-squares (OLS) regression models with fixed effects for time (by year) and state errors when possible. I employ a state-level model of import levels, similar to the model used by Chaudoin et al. (2016) and others. I ran models both with lagged independent variable (testing for a delayed effect) and without this feature (testing for an immediate effect). Following Chaudoin, I also ran models using a logged dependent variable as a robustness check. Effects were similar in these models as well. All models can be found in the appendix. I primarily use the models shown in Table 1 (non-normalized, lagged DV) for discussion due to ease of interpretation.

In order to test Hypothesis 1, I specify the following basic models of state-level service imports to include the political variable of WTO membership and rigorous accession:

$$
\begin{aligned}
\text { Service Sector Imports } s_{i t}= & B_{0}+B_{1} \text { WTO Membership }_{i t}+B_{2} \log (G D P)_{i t}+B_{3} F X \text { Rate }_{i t}+B_{4} \text { FDI Inflows }_{i t}+ \\
& B_{5} \text { OECD Membership } \\
i t & +C_{i}+e
\end{aligned}
$$

The second model examines WTO membership following a rigorous accession:

$$
\begin{aligned}
\text { Service Sector Imports }_{i t}= & B_{0}+B_{1} \text { WTO Membership }_{i t}+B_{2} \text { Rigorous WTO Accession }_{i t}+B_{3} \log (G D P)_{i t}+ \\
& B_{4} F X \text { Rate }_{i t}+B_{5} \text { FDI Inflows } \\
i t & +B_{6} \text { OECD Membership } \\
i t & +C_{i}+e
\end{aligned}
$$

\begin{tabular}{|c|c|c|c|c|}
\hline & \multicolumn{4}{|c|}{ Dependent variable } \\
\hline & \multicolumn{4}{|c|}{ Services imports (millions of USD) } \\
\hline & (1) & (2) & (3) & (4) \\
\hline WTO member & $\begin{array}{c}2,397.547 \\
(2,184.847)\end{array}$ & $\begin{array}{c}2,524.044 \\
(2,188.449)\end{array}$ & $\begin{array}{c}3,914.654 \\
(2,803.791)\end{array}$ & $\begin{array}{c}4,044.832 \\
(2,806.748)\end{array}$ \\
\hline WTO member $\times$ Rigorous & & & $\begin{array}{l}-3,544.809 \\
(4,105.257)\end{array}$ & $\begin{array}{l}-3,552.911 \\
(4,105.243)\end{array}$ \\
\hline Log GDP (billions of USD) & $\begin{array}{c}16,259.900^{* * *} \\
(1,164.724)\end{array}$ & $\begin{array}{c}16,387.850^{* * *} \\
(1,171.634)\end{array}$ & $\begin{array}{c}16,369.830^{* * *} \\
(1,171.753)\end{array}$ & $\begin{array}{c}16,498.250^{* * *} \\
(1,178.648)\end{array}$ \\
\hline $\begin{array}{l}\text { FX rate } \\
\text { (LCU per weighted avg) }\end{array}$ & $\begin{array}{c}-87.214^{* *} \\
(36.832)\end{array}$ & $\begin{array}{c}-85.897^{* *} \\
(36.855)\end{array}$ & $\begin{array}{c}-84.422^{* *} \\
(36.977)\end{array}$ & $\begin{array}{c}-83.097^{* *} \\
(37.000)\end{array}$ \\
\hline $\begin{array}{l}\text { FDI inflows } \\
\text { (billions of USD) }\end{array}$ & $\begin{array}{c}335.795^{* * *} \\
(18.744)\end{array}$ & $\begin{array}{c}335.594^{* * *} \\
(18.745)\end{array}$ & $\begin{array}{l}335.675^{* * *} \\
(18.746)\end{array}$ & $\begin{array}{l}335.474^{* * *} \\
(18.747)\end{array}$ \\
\hline OECD & & $\begin{array}{c}-5,675.655 \\
(5,638.165)\end{array}$ & & $\begin{array}{c}-5,685.208 \\
(5,638.612)\end{array}$ \\
\hline Observations & 1,718 & 1,718 & 1,718 & 1,718 \\
\hline $\mathrm{R}^{2}$ & 0.303 & 0.304 & 0.304 & 0.304 \\
\hline Adjusted $\mathrm{R}^{2}$ & 0.262 & 0.262 & 0.262 & 0.262 \\
\hline F statistic & $\begin{array}{c}176.455^{* * *} \\
(\mathrm{df}=4 ; 1,622)\end{array}$ & $\begin{array}{c}141.367^{* * *} \\
(\mathrm{df}=5 ; 1,621)\end{array}$ & $\begin{array}{c}141.291^{* * *} \\
(\mathrm{df}=5 ; 1,621)\end{array}$ & $\begin{array}{c}117.913^{* * *} \\
(\mathrm{df}=6 ; 1,620)\end{array}$ \\
\hline
\end{tabular}

Table 1. Models of WTO accession and yearly imports (1995-2015)

Notes: Models are panel linear regressions with fixed effects specified for country and year. Robust standard errors in parentheses. ${ }^{*} p<0.1,{ }^{* *} p<$ $0.05,{ }^{* * *} p<0.01$.

LCU, local currency unit. 
In Table 1, the dependent variable is aggregate state-year SSIs in millions of USD. The state-level approach allows for greater model flexibility and the incorporation of fixed effects. ${ }^{4}$ Significant effects come from GDP increases, FDI inflows, and FX rate. All economic variables perform directionally as expected by typical economic models. Model fit was also strong. For services imports, OECD membership was not significant. This is due to the earlier observation that OECD members disproportionately specialize in the services trade and are generally net importers of goods. ${ }^{5}$ Models 2 and 4 are the results of the originally specified model. Given the non-result for the OECD variable, I also display models without the OECD measure as a robustness check of the original models (models 1 and 3). The results are largely unchanged.

Interestingly, the results displayed in Table 1 do not provide statistically significant support for H1 or H2. Neither WTO membership, nor Rigorous WTO Accession are positively associated with increased levels of service imports. ${ }^{6}$ It is important to note that the state-level model typically biases in favor of finding trade relationships (Chaudoin et al. 2016), lending greater reliability to this null effect for services.

In Table 2, I examine several other measures of WTO liberalization pressure. The first model is similar to the models from Table 1, with a new rigorous accession variable replacing the previous interactive model. The effect is largely the same. Next, I test the effect of the number of rounds of questioning in models 2 . This was one of the chief measures that determined the value of the dummy variable for Rigorous accession in the Allee / Scalera data set. States that were subjected to additional rounds of negotiation as a condition of joining the WTO can be expected to have undergone more significant degrees of liberalization. Here I find tentative support for $\mathrm{H} 3$.

Additionally, I measured the impact of general and specific trade commitments in models 3 and 4 . In both cases, states that made more commitments during accession had levels of SSIs post-accession that were on average no different from states that did not make these commitments. While effects were positive, they were not significant, and thus not sufficient to support H4.

Rigorous accession and rounds of questioning were also significantly associated with higher goods sector imports post

Table 2. Alternative models of WTO accession and yearly imports (1995-2015)

\begin{tabular}{|c|c|c|c|c|c|c|}
\hline & \multicolumn{6}{|c|}{ Dependent variable: } \\
\hline & \multicolumn{4}{|c|}{ Services imports (millions of USD) } & \multicolumn{2}{|c|}{ Goods imports (millions of USD) } \\
\hline & (1) & (2) & (3) & (4) & (5) & (6) \\
\hline $\begin{array}{l}\text { Rigorous accession to } \\
\text { the WTO }\end{array}$ & $\begin{array}{c}46.943 \\
(3,200.199)\end{array}$ & & & & $\begin{array}{l}24,240.420^{* *} \\
(14,204.130)\end{array}$ & \\
\hline $\begin{array}{l}\text { Accession rounds of } \\
\text { questioning }\end{array}$ & & $\begin{array}{c}1,086.160^{* * *} \\
(306.696)\end{array}$ & & & & $\begin{array}{l}8,782.182^{* * *} \\
(1,350.260)\end{array}$ \\
\hline $\begin{array}{l}\text { Services commitments } \\
\text { general }\end{array}$ & & & $\begin{array}{c}18.274 \\
(395.328)\end{array}$ & & & \\
\hline $\begin{array}{l}\text { Services commitments } \\
\text { specific }\end{array}$ & & & & $\begin{array}{l}-12.916 \\
(37.002)\end{array}$ & & \\
\hline $\begin{array}{l}\text { Log GDP } \\
\text { (billions of USD) }\end{array}$ & $\begin{array}{c}16,722.030^{* * *} \\
(1,144.613)\end{array}$ & $\begin{array}{c}15,680.340^{* * *} \\
(1,119.975)\end{array}$ & $\begin{array}{c}16,715.270^{* * *} \\
(1,115.713)\end{array}$ & $\begin{array}{c}16,817.530^{* * *} \\
(1,114.691)\end{array}$ & $\begin{array}{c}62,125.040^{* * *} \\
(5,080.381)\end{array}$ & $\begin{array}{c}56,433.670^{* * *} \\
(4,930.799)\end{array}$ \\
\hline $\begin{array}{l}\text { FX rate (LCU per } \\
\text { weighted avg) }\end{array}$ & $\begin{array}{c}-89.752^{* *} \\
(36.790)\end{array}$ & $\begin{array}{c}-84.423^{* *} \\
(36.663)\end{array}$ & $\begin{array}{c}-89.882^{* *} \\
(36.909)\end{array}$ & $\begin{array}{c}-88.730^{* *} \\
(36.886)\end{array}$ & $\begin{array}{c}-327.216^{* *} \\
(163.293)\end{array}$ & $\begin{array}{r}-276.079^{*} \\
(161.414)\end{array}$ \\
\hline $\begin{array}{l}\text { FDI inflows } \\
\text { (billions of USD) }\end{array}$ & $\begin{array}{l}336.800^{* * *} \\
(18.734)\end{array}$ & $\begin{array}{l}330.129^{* * *} \\
(18.751)\end{array}$ & $\begin{array}{l}336.776^{* * *} \\
(18.741)\end{array}$ & $\begin{array}{l}336.981^{* * *} \\
(18.734)\end{array}$ & $\begin{array}{l}1,604.583^{* * *} \\
(83.150)\end{array}$ & $\begin{array}{l}1,554.154^{* * *} \\
(82.553)\end{array}$ \\
\hline Observations & 1,718 & 1,718 & 1,718 & 1,718 & 1,718 & 1,718 \\
\hline $\mathrm{R}^{2}$ & 0.303 & 0.307 & 0.303 & 0.303 & 0.301 & 0.312 \\
\hline Adjusted $\mathrm{R}^{2}$ & 0.262 & 0.266 & 0.262 & 0.262 & 0.260 & 0.271 \\
\hline $\begin{array}{l}\text { F statistic } \\
(\mathrm{df}=4 ; 1,622)\end{array}$ & $176.236^{* * *}$ & $179.433^{* * *}$ & $176.303^{* * *}$ & $176.050^{* * *}$ & $174.213^{* * *}$ & $183.681^{* * *}$ \\
\hline
\end{tabular}

Notes: Models are panel linear regressions with fixed effects specified for country and year. Robust standard errors in parentheses. ${ }^{* *} p<0.1,{ }^{* * *} p<0.01$. LCU, local currency unit.

\footnotetext{
${ }^{4}$ For a similar model of determinants of state-level trade (Antràs et al. 2012). Results are similar to a dyadic model.

${ }^{5}$ The effect of OECD membership was significant for goods imports. Wölfl (2005) or "Member States - About the OECD" for more on this.

${ }^{6} \mathrm{~A}$ regression on goods imports confirmed the Allee Scalera model. A rigorous accession to the WTO was associated with an increase in yearly goods imports of approximately 35 billion USD (Table 2).
} 
accession in these models. These results can be seen included with Table 2 for comparison (models 5 and 6 ). ${ }^{7}$

Economic variables continued to perform as expected. The substantive effect of FX rate was much smaller for services than for goods. This relative inelasticity is reflective of the non-commoditized (branded) nature of most service products relative to goods. Barriers to switching between service providers are naturally higher than switching between manufactured or raw goods. ${ }^{8}$

It is important to pause here and discuss in more detail what might explain these results. As discussed previously, the WTO's liberalization efforts have been strongly focused on the trade in goods. However, even when those efforts have focused on services trade, it remains uncertain as to how effective they were. The debate over IO effectiveness is well-established in the literature, and some have argued that IOs in fact face difficulty in inducing states to make costly commitments (Downs et al. 1996). As a result, many IO outcomes merely formalize non-costly or inevitable behavior. Consistent with this argument, many states were able to join GATS with relatively little change to their service sectors, due either to an unwillingness to lower certain protections or because their protections were low to begin with. This was true with the goods trade (Allee and Scalera 2012 or Rose 2004). As Rose states "[many of] the contracting parties to the ad hoc and provisional GATT signed legal documents about goods trade only to the extent that they were consistent with pre-existing national legislation." It seems equally (if not more) plausible that the same could apply to the GATS.

However, while many states join with little institutional change, others must undergo extensive reform as a condition of membership (Allee and Scalera 2012 or Rose 2004). So what explains the lack of services openness for these "rigorous accessions"? Since the effect is present for the goods trade, the answer must lie with the nature of the GATS regime. Several studies examined GATS in the years following its adoption, and described deficiencies. Suave and Mattoo noted the relatively lax approach of GATS in a 2003 paper on the subject (Sauve and Mattoo 2003), and then again in their 2008 book, citing "a number of loopholes" in the agreement which "allows developing countries particular flexibility in according more favorable treatment to firms and services" (Mattoo and Sauv'e 2008). In the services sector, this favorable treatment often takes the form of protective regulations as opposed to tariffs. Hufbauer and Stephenson take an even stronger tack, arguing that "GATS has in fact played little or no role" in service sector liberalization since its introduction (Hufbauer and Stephenson 2007). In Marchetti's exploration of the creation of GATS, he states that "The GATS... contains too many loopholes to be considered a safe lock-in mechanism for domestic policies" (Marchetti and Mavroidis 2011).

One answer to why negotiating service sector liberalization is so difficult may lie in the differences in how the two sectors are typically protected. Many studies cite domestic regulations, or "NTBs" as the primary means of service sector protectionism. Unfortunately, the WTO's efforts have mostly focused on tariff cutting as opposed to NTB reduction (World Trade Organization 2019b). Service imports are often subject to a higher proportion of NTBs to trade relative to goods, and these barriers can be harder to detect than simple tariffs. The WTO's own website states explicitly that "domestic regulations are the most significant means of exercising influence or control over services trade" (World Trade Organization 2019c). Barth et al. (2006) studied regulatory protectionism in the banking industry and found that countries often exhibit significant differences between their stated commitments and de facto practices. Among the 123 countries studied, "foreign firms are more restricted than domestic firms for all countries and country groupings" (Barth et al. 2006). Measuring these barriers is difficult because rules are often inconsistently enforced or subject to revision on a case-by-case basis. As a result, relative to more-straightforward cuts to goods tariffs, first-round commitments that are made under the GATS are often vague enough that they do not bring about meaningful policy changes.

However, while NBT reduction is more difficult to negotiate, it seems these efforts may have been more effective in some cases where negotiations have been more lengthy. Although the effect is small relative to the goods trade, Table 2 demonstrates that additional rounds of questioning did have a significant effect on inducing SSIs. One possible reason for this is simple, although perhaps not apparent at first. Additional rounds of questioning give negotiators additional information to learn the complexity of service sector regulation. Marchetti describes that during the negotiation of the GATS "negotiators spent the first three years essentially educating themselves by asking questions". As mentioned earlier, it also may indicate that these states were starting from a point of relatively greater protectionism, creating a greater space for liberalization. Either way, it follows that cases which feature additional rounds of questioning are more likely to feature meaningful liberalization.

The models in Table 2 provide some support for this idea. However, notably, this result was not robust to an alternative

\footnotetext{
${ }^{7}$ Each additional round during accession was associated with an increase in goods imports of roughly 7.5 billion USD, and a rigorous accession was associated with an increase of 35 billion USD.

${ }^{8}$ See Patterson and Smith (2003) for an exploration of this stylized fact.
} 
specification using a logged dependent variable (Appendix 4). By examining some historical cases where there were a high number of rounds of questioning before accession, we can learn more about exactly how and when (and if) additional negotiating time can lead to more meaningful liberalization.

\section{Service sector negotiations and the WTO}

In order to examine the question of negotiation more thoroughly, I examine two significant WTO accession cases. These cases are significant because they represent the cases with the greatest number of negotiating rounds before the states were admitted to the organization. ${ }^{9}$ As we will see, this additional negotiation time can have significant effects on the level of service sector liberalization, but only in certain contexts. These states, China and Vietnam, had very different negotiation processes. Only when this process involved significant changes to the structure of the economy was the WTO able to induce significant change. The case study approach allows us to isolate the most probable mechanism for WTO-induced liberalization, rigorous accession, while examining an important conditioning qualitative variables: political willingness to liberalize, expertise, and initial levels of protection.

China joining the WTO was one of the most significant events in the history of the organization. Before accession, China was generally understood to be highly protectionist. In order to join, China had to undergo what most would call a "rigorous" accession process, constituting 19 rounds of questioning (Allee and Scalera 2012). Seemingly as a result, significant portions of the Chinese economy were liberalized, including the service sector (Kanungo 2005).

However, the accession of China to the WTO was closely negotiated by the Chinese. China was able to leverage strong US interest in the Chinese market to remain stubborn even on relaxing goods trade protections, an area where they already held a comparative advantage. Nearly every immediate concession made was related to goods tariffs, and service sector commitments had a broad runway. While China promised some service reforms (Mattoo 2002), as deadlines approached these changes looked increasingly unlikely to occur, and analysts expressed concern that the WTO would prove ineffective at inducing them (Whalley 2003). All of the issues discussed in the preceding section, particularly regarding NTBs, are applicable to the China case. China is well-known for its restrictive markets. Companies wishing to offer services there are often subject to partial nationalization, strict oversight bordering on espionage, and forced technology transfers (Holmes et al. 2015). Each of these can be thought of as varying types of NTB measures. In many cases, such as in the financial services trade, China even adopted a slew of new regulations on the eve of their accession in order to buffer the impact to this sector (Schneider 2007).

Despite the promises of liberalization, China has been slow to reduce these barriers after gaining admission to the WTO. Several years after China was admitted and two years before most commitments were meant to be finalized, Kanungo (2005) noted that "the slow reform process coupled with a continuation of restrictions... are delaying [service sector] gains" (Kanungo 2005). More recent studies have noted that modest initial gains in service sector openness have largely leveled off (Chen and Whalley 2014), and significant regulatory barriers to trade still exist, particularly at the local level (Gao 2018). China maintains these barriers by claiming exemption to WTO mandates due to its status as a "developing county" (World Trade Organization 2019b). Prevailing political trends in the Chinese Communist Party have continued to ensure that protectionist tendencies remain strong, and this stance seems unlikely to change (Lake 2018). This all underscores earlier points about the GATS, which is to say that the agreement provides ample cover for states that do not wish to truly liberalize. In the case of China, it is quite unclear whether the WTO was successful in inducing significant opening of the services sector.

In Vietnam, a very different type of scenario prevailed. The country was in the midst of an economic transformation from a protectionist, centrally planned economy into a state-led market economy. Due to the heavy involvement of the state in Vietnam's economy, their accession negotiation was also quite lengthy (lasting 17 rounds of questioning), similar to China's. However, unlike China, Vietnam did not have strong leverage over the WTO to resist making costly concessions. Their accession was part of a broader effort to strike more favorable trade terms with the major economies and secure access to their markets for goods exports, in which Vietnam has a strong competitive advantage. They signed a significant bilateral trade agreement with the USA in 2000 to this effect (Office of the US Trade Representative, 2000). As a result of their accession, Vietnam made considerable concessions on services trade, and subsequently became a major hub for FDI in the region (Thanh and Duong 2009). As we have seen, FDI is a predictor of imports in both goods and services.

In Vietnam, it also seems reasonable to expect that WTO accession produced positive shock to service sector trade imports.

${ }^{9}$ Ukraine is also included in this group, but is excluded due to a variety of endogenous factors that impacted both the accesssion process and subsequent trade growth. 
Vietnam exhibits little control over FDI the way China does, and did not have a mature services market when they joined the WTO. These features make it more likely that liberalization was able to take root.

In summary, it seems clear that the number of negotiating rounds is connected at least in part to the level of initial protectionism. However, these negotiations result in opening only under specific conditions. I expect that the WTO has only been able to facilitate increases in services trade when the acceding state is open to liberalization in the first place, and when the WTO has more negotiating leverage. When the state is not interested in liberalization, loopholes and exceptions in the GATS make it possible for a state to avoid increasing service sector openness. Even for states undergoing rigorous negotiations or subjecting themselves to a number of commitments, these outcomes may or may not translate to actual gains in service sector openness due to the weakness of GATS.

H5: Rigorous accession that occurs in an accommodating political environment, or an environment in which Working Party negotiators hold a comparative advantage in expertise, will result in higher levels of service trade inflows post-accession (Vietnam) than similar cases where these conditions are not met (China).

\subsection{Case study data}

The state-specific dyadic data used for testing was collected from the World Trade Organization's International Trade and Tariff Data and contains over 100,000 cases on trade in every sector (World Trade Organization 2019a). The membership and accession data were carried from the previous models. Several of the control variables were the same as the first models, but analysis at the state-dyad level allows for incorporation of dyad-specific variables such as distance and language, consistent with the gravity model. As discussed previously, particularly in the service sector, there is reason to believe that the gravity model should apply. The variables employed here are similar to those utilized by Kimura and Lee (2006).

Interestingly, as illustrated in Figure 4(a), the share of service sector trade in China has declined since the country joined the WTO. Certainly a portion of this effect is due to the tremendous growth of the goods trade. However, even among goodsexporting states, this is atypical. Vietnam also saw a reduction in service sector trade as they continued to industrialize, but this trend softened following their accession, shown in Figure 4(b). Some similarly endowed states such as Mexico have seen strong manufacturing growth and have even seen increases in service trade as an overall contributor to GDP (World Bank 2019).

China was an exception for two reasons. Firstly, it was the only state of the three that had a clear reversal of trend postaccession, but this trend was moving in the opposite direction of what we would expect if the WTO had induced significant opening. Secondly, China is relatively closed to services trade, exhibiting levels of services trade less than half that of Vietnam.

In order to examine this a bit further, I examined service sector trade openness in the Asia region over the period from 2000 to 2010. These initial 10 years of China's WTO membership should have seen the largest effects from service sector trade liberalization. Trade openness was measured by SSIs as a share of GDP. Interestingly, while the rest of the region increased in openness during the period, China actually measured a slight decrease. For 2000, service imports represented $2.99 \%$ of China's GDP, compared with $2.31 \%$ in 2010. Over the period, China's SSI to GDP ratio peaked in 2004 at 3.7\%, and was still only about a percent higher than the USA, a leading services exporter. It was nearly half the SSI to GDP ratio of the Philippines, and a third of that of Vietnam, both regional neighbors with similar development profiles.

To be clear, China has clearly reduced some barriers to service sector trade relative to its earlier standing. However, China

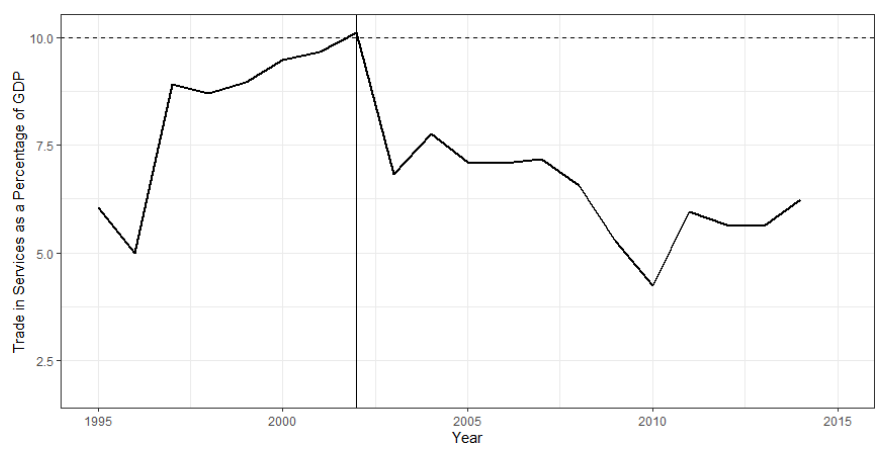

(a)

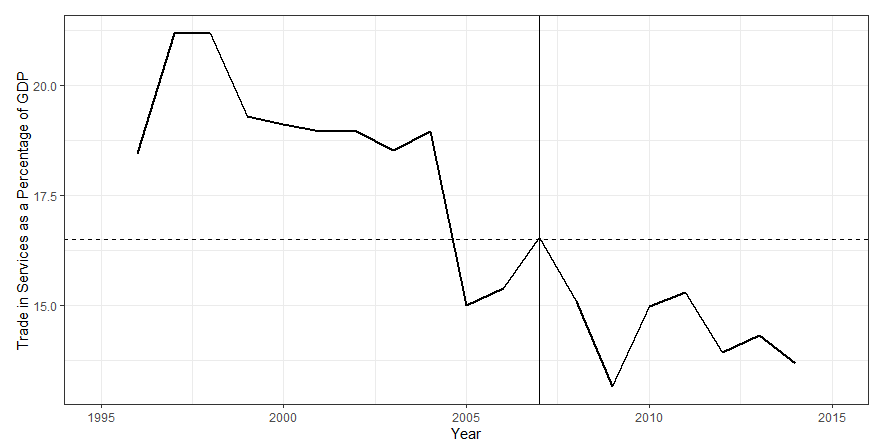

(b)

Figure 4. Share of services trade since accession. (a) China (\% of GDP), (b) Vietnam (\% of GDP). 
was already in the process of this liberalization by the time it joined the WTO. China was generally understood to be "under trading" before joining the WTO, and was already well on its way to liberalization by 2002 (Ianchovichina and Martin 2001). This effect appears to be independent of the WTO. Once China joined the WTO, much of this liberalization actually slowed or stopped altogether. This is especially true of the service sector.

\subsection{Case study results}

In order to specify a gravity model of trade, I add two measures. The first of these is Region, which proxies the geographical distance between the state and the partner state, assuming that longer distances will reduce services trade. The second is Language, a dummy variable which measures linguistic similarity between the two states in the dyad, assuming that states with more same-speaking residents will be more inclined to trade in services. Most gravity models also include a measure of partnerstate economic development, which I proxy by retaining my OECD measure. The positive association between OECD membership and goods imports found in Table 1 serves as a basis for inclusion of this variable in the state-specific analysis. States in the OECD export more services on average than other states, thus this variable is potentially a significant predictor of SSIs from a partner state. ${ }^{10}$

In all models, I focus on the period after GATS was formalized in 1995. As discussed in the previous section, formalized rules on the service sector were nascent or nonexistent before this point, so a proper theoretical focus should begin here. As with the previous models, Rigorous WTO Accession is coded as 1 round or more of negotiations.

One factor that can be examined in the state-dyadic model is whether or not both trading partners were members of the WTO. Proponents of the argument that the WTO directly increases trade growth cite reciprocity as an important factor (Goldstein et al. 2007). Therefore, we should expect any WTO-caused growth in service sector trade with a partner state to be present primarily when both states are members of the WTO, which is how I design my models.

For these cases, I specify the below model, similar to the first. Here I apply the gravity model variables and adjust the dependent variables slightly to test H5:

$$
\begin{aligned}
{\text { Services Imports to } \text { State }_{i t}=} & B_{0}+B_{1} \text { WTO Member }_{i t}+B_{2} \log (G D P)_{i t}+B_{3} \text { FXrate }_{i t}+B_{4} \text { Language }_{i t}+ \\
& B_{5} \text { Region }_{i t}+B_{6} \text { OECD Partner }_{i t}+C_{i}+e
\end{aligned}
$$

In Table 3, I measure service sector exports to the state in question from over 160 trading partners. The dependent variable is state-partner-year dyadic import volume in billions of USD.

As with the previous test, economic variables performed largely as expected. The OECD variable continues to perform as a proxy for relative size and service specialization. Model fit is also fairly strong in this model.

China's WTO accession did not impact its services imports in a significant way when controlling for economic variables. This provides tentative support for the hypothesis, and indicates that even in this case of extremely rigorous accession (19 rounds), the WTO was not able to induce a significant opening of the service sector in China. As detailed in the preceding sections, while their accession may or may not have produced real gains in the goods trade, China did little to meaningfully open its market to foreign services. Most of its service sector commitments were either insignificant or never executed. The provisions of the GATS make this outcome all but inevitable for states that are not interested in following the spirit of the agreement. Although the negotiation was lengthy, much of the effort was focused on trade in goods.

Conversely, the Model 3 results for Vietnam were significant. Although far from conclusive, this provides some tentative support for the hypothesis and the idea that some rigorous accessions can be effective when certain conditions prevail, namely that the state is genuinely interested in liberalizing and there is enough time and negotiation space to craft meaningful reforms. Despite continuing its rapid growth trajectory both before and after accession, relative services imports were positively associated with the period after accession, owing to Vietnam's opening to foreign investment. After 17 rounds of negotiation and questions, it seems plausible that the WTO was able to induce significant and structural changes as a result of Vietnam's final accession terms. However, Model 4, which utilized a logged dependent variable, did not find support. This mixed result merits further investigation.

\footnotetext{
${ }^{10}$ This variable is also associated with several other features that predict trade levels, making it a useful proxy variable (see Wölfl 2005 or "Member States - About the OECD" for more on this).
} 
Table 3. Service exports to China and Vietnam

\begin{tabular}{|c|c|c|c|c|}
\hline & \multicolumn{4}{|c|}{ Dependent variable: } \\
\hline & \multicolumn{4}{|c|}{ Services imports (millions of USD) } \\
\hline & China (1) & China (2) & Vietnam (3) & Vietnam (4) \\
\hline State in WTO & $\begin{array}{l}-338.023 \\
(263.548)\end{array}$ & $\begin{array}{c}0.204 \\
(0.153)\end{array}$ & $\begin{array}{l}39.217^{* *} \\
(21.778)\end{array}$ & $\begin{array}{c}0.170 \\
(0.237)\end{array}$ \\
\hline $\log (\mathrm{GDP})$ & $\begin{array}{c}1,194.196 * * * \\
(202.473)\end{array}$ & $\begin{array}{l}1.240^{* * *} \\
(0.117)\end{array}$ & $\begin{array}{c}21.389 \\
(29.071)\end{array}$ & $\begin{array}{c}0.913^{* * *} \\
(0.316)\end{array}$ \\
\hline FX rate & $\begin{array}{c}-1.000 \\
(14.906)\end{array}$ & $\begin{array}{c}-0.015^{* *} \\
(0.009)\end{array}$ & $\begin{array}{c}0.004 \\
(0.005)\end{array}$ & $\begin{array}{l}0.00003 \\
(0.0001)\end{array}$ \\
\hline Same language & $\begin{array}{c}6,351.176^{* * * *} \\
(438.572)\end{array}$ & $\begin{array}{l}3.110^{* * * *} \\
(0.254)\end{array}$ & & \\
\hline Same region & $\begin{array}{c}1,539.090^{* * * *} \\
(218.841)\end{array}$ & $\begin{array}{l}2.411^{* * * *} \\
(0.127)\end{array}$ & $\begin{array}{l}185.095^{* * *} \\
(19.556)\end{array}$ & $\begin{array}{l}3.988^{* * * *} \\
(0.213)\end{array}$ \\
\hline Partner in OECD in 1995 & $\begin{array}{c}1,564.664^{* * *} \\
(163.115)\end{array}$ & $\begin{array}{l}2.824^{* * * *} \\
(0.094)\end{array}$ & $\begin{array}{c}100.247^{* * * *} \\
(9.186)\end{array}$ & $\begin{array}{l}2.688^{* * * *} \\
(0.100)\end{array}$ \\
\hline Constant & $\begin{array}{c}-6,171.689^{* * *} \\
(1,010.158)\end{array}$ & $\begin{array}{c}-31.133^{* * *} \\
(2.775)\end{array}$ & $\begin{array}{l}-592.303 \\
(647.965)\end{array}$ & $\begin{array}{c}-22.359^{* * *} \\
(7.050)\end{array}$ \\
\hline Observations & 1,332 & 1,332 & 1,332 & 1,332 \\
\hline $\mathrm{R}^{2}$ & 0.300 & 0.604 & 0.169 & 0.467 \\
\hline Adjusted $\mathrm{R}^{2}$ & 0.297 & 0.602 & 0.166 & 0.465 \\
\hline Residual Std. error & $2,830.489(\mathrm{df}=1,325)$ & $1 / 638(\mathrm{df}=1,326)$ & $158.717(\mathrm{df}=1,326)$ & $1.725(\mathrm{df}=1,326)$ \\
\hline F statistic & $94.702^{* * *}(\mathrm{df}=6 ; 1,325)$ & $336.434^{* * *}(\mathrm{df}=6 ; 1,325)$ & $53.838^{* * *}(\mathrm{df}=5 ; 1,326)$ & $232.103^{* * *}(\mathrm{df}=5 ; 1,326)$ \\
\hline
\end{tabular}

Notes: ${ }^{*} p<0.1,{ }^{* *} p<0.05,{ }^{* * *} p<0.01$; Values use one-tailed hypothesis.

Robust standard errors in parentheses. All partner states are WTO members as of Jan 1, 1995.

Notably, FDI is excluded from these models. It was found not to have an impact on imports for China. A possible explanation for this in the case of China is that China continues to maintain a mostly-closed market with respect to foreign service providers establishing independent local operations. Establishing a presence in China, even 20 years after their accession to the WTO, is still notoriously difficult for service providers (Staff 2019). As discussed previously, FDI restrictions can serve as a key NTBs, especially for services.

In Vietnam, the FDI situation is quite different. FDI was highly correlated with the period after accession, and including FDI washed out the effect of WTO accession. This highlights the points made earlier about FDI and the services trade in Vietnam. The nature of the positive shock to services trade following accession in Vietnam seems closely linked to FDI. The WTO negotiation process resulted in an opening of the country to foreign development, and this investment created a surge in imports of services.

FX rate also loses most significance in this model. Along with the reasons discussed for Table 1, both states had pegged currencies at the start of the period, and now both states maintain crawling pegs or managed floats. Many states maintain pegs as a way of managing currency competitiveness and stability in order to reduce costs for exporters (Broz and Frieden 2001). Therefore in these cases it is unsurprising to see a muted effect for currency movements, as avoiding these shocks is the whole point of the policy. Model 2 for China did exhibit significance for FX rate.

\section{Discussion of implications and future research (Conclusion)}

Again, the accession argument suggests that states are willing to make costly concessions (in the form of lowering trade barriers) in exchange for the benefits of WTO membership. However, when examining the services trade, the majority of states that have joined the WTO either joined before GATS was instituted, or joined after GATS but did not need to make substantial changes to service sector rules. This was either because they already maintained a degree of service sector openness, or because GATS itself allowed for protections to be kept. Together this eliminates any service sector trade increase from the WTO accession process in most cases. As just described, China is a case-in-point. We can suspect that China's service sector trade openness was not significantly impacted by its WTO accession. The GATS framework simply provides too many exceptions and too little direct guidance to be effective when there is strong resistance. Conversely, it is plausible that negotiations can be 
an effective liberalization mechanism when the acceding state is both relatively closed to begin with and open to liberalization, such as in the case of Vietnam.

Without question, the rise in WTO membership has been accompanied by an unprecedented rise in the total volume of global trade and by a reduction of tariffs and NTBs. However, the mere presence of these coinciding trends does not necessarily imply causation, and makes conclusive empirical analysis more difficult (Granger and Newbold 1974). Critical study must try to question our assumptions and disentangle how much of this growth and tariff cutting would have occurred in the absence of a WTO. There are many reasons that international services trade has increased, and protectionism has decreased since 1995. Improving technology, increased competition in international markets, and the spread of consumer markets have all been cited as possible alternative explanations, among other theories (Blanchard 2010; Drezner 2001; Rudra 2002; Rose 2004).

While the WTO has certainly played a role in facilitating some of these reductions in trade barriers, this seems to have occurred only in certain circumstances, namely rigorous accessions where states faced a strong incentive to cooperate and negotiators had enough time to develop meaningful reform conditions. However, even these cases, the WTO is facilitating and formalizing liberalization, but it is not clear that it is truly enforcing it, as the nature of GATS would allow any acceding state to circumvent meaningful reductions in trade barriers if they wished, such as in the China case. Furthermore, any ongoing effect from membership or the threat of arbitration remains purely theoretical for services trade.

The question of whether or not liberalization would have occurred inevitably without the WTO is less meaningful from a policy standpoint. What is more important is what the WTO will do moving forward. Now that nearly every state is a member and the first waves of liberalization (in the goods trade) have occurred, will WTO membership continue to have a meaningful effect? Secondly, what will the policy focus of the WTO be moving forward? The WTO has generally focused on the goods trade, which is where we observe the most important results of its actions. However, as more states develop service based economies, the WTO will need to sharpen its approach to the service industries in order to maintain it relevance. The unsuccessful Doha Round has attempted to address some key service sector issues such as movement of people and FDI restrictions, but these efforts have made little headway. The GATS framework remains unevenly implemented and too vague to be effective.

The second set of negotiations around services trade began with the Doha round in 2001, but aside from updating the agreement on general principles, no progress has been made since that time (Barth et al. 2006 for discussion of early Doha negotiations). Developing states that have less competitive service sectors have since hardened their positions and made it difficult to further develop GATS rules. As of the time of this writing, the WTO dispute settlement body is at danger of becoming non-functioning. In the face of such failures and under increasingly hostile scrutiny and criticism, the question of efficacy merits serious consideration. Many states are moving away from the WTO model of broad trade consensus, now favoring bilateral investment treaties (BITs) or preferential trade agreements (PTAs), while simultaneously backing away from broader commitments. While these smaller agreements may encourage some liberalization, the effect is far narrower and may even encourage broader trade antagonism or factionalism.

The effect of WTO membership on trade volumes has been subject to much debate, but critically, these studies have failed to examine service sector trade specifically. In this paper, I argue that when the WTO has pursued services trade liberalization, measurable effects have been present in only a small subset of rigorously negotiated cases. This is due to the differences between the ways that the goods trade and the services trade are regulated, as well as the weakness of WTO provisions such as GATS at inducing specific, costly reductions in service sector protectionism. These findings imply that the WTO has under-emphasized service sector trade, potentially disadvantaging certain member-states. However, they also suggest that progress is possible, and is most likely when negotiators have time to learn the complexities of service sector regulation and seek meaningful reform, as opposed to settling on a quick (or long) "win". It also suggests that accession-style negotiations, which feature more focus on a single economy and less veto-players, may be the best framework for future progress. As the global economy becomes increasingly dominated by the service sector, understanding how international trade organizations such as the WTO impact it will become increasingly important. As politicians around the world continue to make political hay out of IGO ineffectiveness, the WTO can ill afford to ignore these gaps.

Future research should continue to examine the effects of WTO membership at a more granular level. Protectionism in the service sector is more diverse than in the goods sector, and specificity is therefore even more important, especially as the WTO continues to adjust its policy program for the 21 st century. Sub-sector specific and industry level examination would accomplish this and would make any academic results more easily translatable into policy prescriptions. Understanding variation in how the GATS was implemented will also help inform future agreements. More specifically and in both cases, a closer examination of NTBs is also warranted, if not overdue. 


\section{Acknowledgements}

Chase Englund is a Ph.D. Student in the Department of Government and Politics, University of Maryland, College Park MD, and a Graduate Economic Fellow at the Board of Governors of the US Federal Reserve. Email: cenglund@umd.edu. Thanks to Todd Allee, Scott Kastner and Margaret Pearson at the University of Maryland for assistance and to all others who graciously provided comments and feedback on this paper.

\section{References}

Allee, T. L., Scalera, J. E., 2012. The divergent effects of joining international organizations: Trade gains and the rigors of WTO accession. International Organization 66, 243-276.

Antr'as, P., Chor, D., Fally, T., Hillberry, R., 2012. Measuring the upstreamness of production and trade flows. American Economic Review 102, 412-416.

Baggs, J., Beaulieu, E., Fung, L., 2010. Are service firms affected by exchange rate movements? Review of Income and Wealth 56, S156-S176.

Barattieri, A., 2014. Comparative advantage, service trade, and global imbalances. Journal of International Economics 92, 113.

Barth, J. R., Marchetti, J. A., Nolle, D. E., Sawangngoenyuang, W., 2006. Foreign banking: Do countries' WTO commitments match actual practices? WTO Staff Working Paper No. ERSD-2006-11.

Blanchard, E. J., 2010. Reevaluating the role of trade agreements: Does investment globalization make the WTO obsolete? Journal of International Economics 82, 63-72.

Broz, J. L., Frieden, J. A., 2001. The political economy of international monetary relations. Annual Review of Political Science 4, 317-343.

Chaudoin, S., Kucik, J., Pelc, K., 2016. Do WTO disputes actually increase trade? International Studies Quarterly 60, 294-306. Chen, H., Whalley, J., 2014. China's service trade. Journal of Economic Surveys 28, 746-774.

Dee, P., Ferrantino, M., 2005. Quantitative Methods for Assessing the Effects of Non-Tariff Measures and Trade Facilitation. World Scientific Publishing Company, Singapore.

Downs, G. W., Rocke, D. M., Barsoom, P. N., 1996. Is the good news about compliance good news about cooperation? International Organization 50, 379-406.

Drezner, D. W., 2001. Globalization and policy convergence. International Studies Review 3, 53-78.

Eicher, T. S., Henn, C., 2011. In search of WTO trade effects: Preferential trade agreements promote trade strongly, but unevenly. Journal of International Economics 83, 137-153.

Evenett, S. J., Braga, C. A. P., 2005. WTO Accession: Lessons from Experience. World Bank, Washington, DC.

Federal Reserve Bank of St. Louis, 2017. U.S. trade deficit driven by goods, not services. Federal Reserve Bank of St. Louis. Available at: https://www.stlouisfed.org/on-the-economy/2017/june/us-trade-deficit-driven-goods-services

Gao, H. S., 2018. The WTO transparency obligations and China. The Journal of Comparative Law 12, 329-355.

Granger, C. W. J., Newbold, P., 1974. Spurious regressions in econometrics. Journal of Econometrics 2, 111-120.

Goldstein, J. L., Rivers, D., Tomz, M., 2007. Institutions in international relations: Understanding the effects of the GATT and the WTO on world trade. International Organization 61, 37-67.

Holmes, T. J., Mcgrattan, E. R., Prescott, E. C., 2015. Quid pro quo: Technology capital transfers for market access in China. The Review of Economic Studies 82, 1154-1193.

Hufbauer, G., Stephenson, S., 2007. Services trade: Past liberalization and future challenges. Journal of International Economic Law 10, 605-630.

Ianchovichina, E., Martin, W., 2001. Trade Liberalization in China's Accession to the World Trade Organization. World Bank, Washington, DC.

Kimura, F., Lee, H. H., 2006. The gravity equation in international trade in services. Review of World Economics 142, 92-121.

Kanungo, A. K., 2005. Service sector in China after its accession to the WTO. International Studies 42, 229-345.

Kelsey, J., 2016. From GATS to TiSA: Pushing the trade in services regime beyond the limits. In: Bungenberg, M., Herrmann, C., Krajewski, M., Terhechte, J. (Eds), European Yearbook of International Economic Law. Springer, Cham, Switzerland.

Lake, D. A., 2018. Economic openness and great power competition: Lessons for China and the United States. The Chinese Journal of International Politics 11, 237-270. 
Marchetti, J. A., Mavroidis, P. C., 2011. The genesis of the GATS (general agreement on trade in services). European Journal of International Law 22, 689-721.

Mattoo, A., 2002. China's accession to the WTO: The services dimension. Journal of International Economic Law 6, 299-339.

Nordstrom, T., Warnke, K., 2004. The COW-2 international organizations dataset version 2.0. Conflict Management and Peace Science 21, 101-119.

Office of the US Trade Representative, 2000. Agreement between the United States of America and the Socialist Republic of Vietnam on trade relations. Available at: https:/ustr.gov/sites/default/files/US-VietNam-BilateralTradeAgreement.pdf

Patterson, P. G., Smith, T., 2003. A cross-cultural study of switching barriers and propensity to stay with service providers. Journal of Retailing 79, 107-120.

Rose, A. K., 2004. Do we really know that the WTO increases trade? American Economic Review 94, 98-114.

Rudra, N., 2002. Globalization and the decline of the welfare state in less-developed countries. International Organization 56, 411-445.

Schneider, E. F., 2007. Be careful what you wish for: China's protectionist regulations of foreign direct investment implemented in the months before completing WTO accession. Brooklyn Journal of Corporate, Financial \& Commercial Law 2, 267.

Staff, R., 2019. JPMorgan Confirms Winning Bid to take Majority Stake in China Fund JV. Reuters. Available at: https://www.reuters.com/article/us-jp-morgan-china-funds-idUSKCN1UW09X

Subramanian, A., Wei, S. J., 2007. The WTO promotes trade, strongly but unevenly. Journal of International Economics 72, 151-175.

Thanh, V. T., Duong, N. A., 2009. Vietnam after two years of WTO accession: What lessons can be learnt? ASEAN Economic Bulletin 26, 115-135.

U.S. Bureau of Labor Statistics, 2018. Employment by major industry sector. U.S. Bureau of Labor Statistics. Available at: https://www.bls.gov/emp/tables/employment-by-major-industry-sector.htm

van Welsum, D., 2003. International Trade in Services: Issues and Concepts. University of London, London, UK.

Whalley, J., 2003. Liberalization in China's key service sectors following WTO accession: Some scenarios and issues of measurement. NBER Working Paper No. w10143.

W“olfl, A., 2005. The Service Economy in OECD Countries. OECD, Paris, France.

World Bank, 2019. World Development Indicators, GDP by Country. Washington, DC.

World Trade Organization, 2019a. International Trade and Tariff Data. WTO, Geneva, Switzerland.

World Trade Organization, 2019b. Schedules of concessions. Available at: https://www.wto.org/english/tratope/schedules $/$ goods $_{s}$ chedules $_{\mathrm{e}} \mathrm{htm}$

World Trade Organization, 2019c. Understanding the WTO - services: Rules for growth and investment. Available at: https://www.wto.org/english/thewto $/$ whatis $_{\mathrm{e}} / \mathrm{tif}_{\mathrm{e}} / \mathrm{agrm6}_{\mathrm{e}} \cdot \mathrm{htm}$ 
Appendix 1. Models of WTO accession and yearly imports (1995-2015) - immediate effect

\begin{tabular}{|c|c|c|c|c|}
\hline & \multicolumn{4}{|c|}{ Dependent variable: } \\
\hline & \multicolumn{4}{|c|}{ Services imports (millions of USD) } \\
\hline & (1) & (2) & (3) & (4) \\
\hline WTO member $\times$ Rigorous & & & $\begin{array}{l}-3,641.036 \\
(7,408.577)\end{array}$ & $\begin{array}{c}-3,708.498 \\
(7,409.452)\end{array}$ \\
\hline $\begin{array}{l}\text { FX rate } \\
\text { (LCU per weighted avg) }\end{array}$ & $\begin{array}{l}-89.848^{* *} \\
(36.758)\end{array}$ & $\begin{array}{c}-88.806^{* *} \\
(36.799)\end{array}$ & $\begin{array}{c}-89.747 * * \\
(36.767)\end{array}$ & $\begin{array}{c}-88.697^{* *} \\
(36.788)\end{array}$ \\
\hline FDI inflows (billions of USD) & $\begin{array}{c}336.155^{* * *} \\
(18.727)\end{array}$ & $\begin{array}{c}336.049^{* * *} \\
(18.729)\end{array}$ & $\begin{array}{c}336.356^{* * *} \\
(18.736)\end{array}$ & $\begin{array}{c}336.254^{* * *} \\
(18.738)\end{array}$ \\
\hline OECD & & $\begin{array}{l}-4,975.157 \\
(5,635.822)\end{array}$ & & $\begin{array}{c}-5,004.098 \\
(5,637.422)\end{array}$ \\
\hline Adjusted $\mathrm{R}^{2}$ & 0.263 & 0.262 & 0.262 & 0.262 \\
\hline F statistic & $\begin{array}{c}176.548^{* * *} \\
(\mathrm{df}=4 ; 1,622)\end{array}$ & $\begin{array}{c}141.375^{* * *} \\
(\mathrm{df}=5 ; 1,621)\end{array}$ & $\begin{array}{c}141.221^{* * *} \\
(\mathrm{df}=5 ; 1,621)\end{array}$ & $\begin{array}{c}117.800^{* * *} \\
(\mathrm{df}=6 ; 1,620)\end{array}$ \\
\hline
\end{tabular}

Notes: Models are panel linear regressions with fixed effects specified for country and year. Robust standard errors in parentheses. ${ }^{*} p<0.1 ;{ }^{* *} p<$ $0.05 ;{ }^{* * *} p<0.01$.

LCU, local currency unit.

\section{Appendix 2. Alternative models of WTO accession and yearly imports (1995-2015) - immediate effect}

\begin{tabular}{|c|c|c|c|c|c|c|}
\hline & \multicolumn{6}{|c|}{ Dependent variable: } \\
\hline & \multicolumn{4}{|c|}{ Services imports (millions of USD) } & \multicolumn{2}{|c|}{ Goods imports (millions of USD) } \\
\hline & (1) & $(2)$ & (3) & (4) & $(5)$ & $(6)$ \\
\hline Rigorous accession to the WTO & $\begin{array}{c}3,001.557 \\
(3,890.845)\end{array}$ & & & & $\begin{array}{l}34,857.660^{* *} \\
(17,266.560)\end{array}$ & \\
\hline Accession rounds of questioning & & $\begin{array}{l}954.630^{* * *} \\
(309.535)\end{array}$ & & & & $\begin{array}{l}7,562.007^{* * *} \\
(1,366.293)\end{array}$ \\
\hline Services commitments general & & & $\begin{array}{c}428.560 \\
(484.464)\end{array}$ & & & \\
\hline Services commitments specific & & & & $\begin{array}{c}11.794 \\
(42.694)\end{array}$ & & \\
\hline Log GDP (billions of USD) & $\begin{array}{c}16,473.670^{* * *} \\
(1,133.006)\end{array}$ & $\begin{array}{c}15,869.000^{* * *} \\
(1,116.498)\end{array}$ & $\begin{array}{c}16,550.710^{* * *} \\
(1,102.399)\end{array}$ & $\begin{array}{c}16,672.180^{* * *} \\
(1,102.660)\end{array}$ & $\begin{array}{c}61,953.090^{* * *} \\
(5,027.987)\end{array}$ & $\begin{array}{c}58,100.010^{* * *} \\
(4,928.241)\end{array}$ \\
\hline FX rate (LCU per weighted avg) & $\begin{array}{c}-89.880^{* *} \\
(36.768)\end{array}$ & $\begin{array}{c}-84.753^{* *} \\
(36.702)\end{array}$ & $\begin{array}{c}-91.680^{* *} \\
(36.831)\end{array}$ & $\begin{array}{c}-90.335^{* *} \\
(36.837)\end{array}$ & $\begin{array}{c}-320.706^{* *} \\
(163.166)\end{array}$ & $\begin{array}{c}-279.566^{*} \\
(162.005)\end{array}$ \\
\hline FDI inflows (billions of USD) & $\begin{array}{l}336.287^{* * *} \\
(18.737)\end{array}$ & $\begin{array}{l}331.707^{* * *} \\
(18.746)\end{array}$ & $\begin{array}{l}335.998^{* * *} \\
(18.746)\end{array}$ & $\begin{array}{l}336.633^{* * *} \\
(18.738)\end{array}$ & $\begin{array}{c}1,602.107^{* * *} \\
(83.148)\end{array}$ & $\begin{array}{c}1,567.751^{* * *} \\
(82.747)\end{array}$ \\
\hline Observations & 1,718 & 1,718 & 1,718 & 1,718 & 1,718 & 1,718 \\
\hline $\mathrm{R}^{2}$ & 0.303 & 0.307 & 0.303 & 0.303 & 0.301 & 0.312 \\
\hline Adjusted $\mathrm{R}^{2}$ & 0.262 & 0.266 & 0.262 & 0.262 & 0.260 & 0.271 \\
\hline F statistic $(\mathrm{df}=4 ; 1,622)$ & $176.236^{* * *}$ & $179.433^{* * *}$ & $176.303^{* * *}$ & $176.050^{* * *}$ & $174.213^{* * *}$ & $183.681^{* * *}$ \\
\hline
\end{tabular}

Notes: Models are panel linear regressions with fixed effects specified for country and year. Robust standard errors in parentheses. ${ }^{*} p<0.1,{ }^{* *} p<$ $0.05,{ }^{* * *} p<0.01$.

LCU, local currency unit. 
Appendix 3. Models of WTO accession and yearly imports (1995-2015) - Log dependent variable

\begin{tabular}{|c|c|c|c|c|}
\hline & \multicolumn{4}{|c|}{ Dependent variable: } \\
\hline & \multicolumn{4}{|c|}{ Services imports (Log millions of USD) } \\
\hline & (1) & (2) & (3) & (4) \\
\hline WTO member & $\begin{array}{c}0.044 \\
(0.025)\end{array}$ & $\begin{array}{c}0.044 \\
(0.025)\end{array}$ & $\begin{array}{c}0.054 \\
(0.032)\end{array}$ & $\begin{array}{c}0.054 \\
(0.032)\end{array}$ \\
\hline WTO member $\times$ Rigorous & & & $\begin{array}{l}-0.022 \\
(0.047)\end{array}$ & $\begin{array}{l}-0.022 \\
(0.047)\end{array}$ \\
\hline Log GDP (billions of USD) & $\begin{array}{l}1.034^{* * *} \\
(0.013)\end{array}$ & $\begin{array}{l}1.034^{* * *} \\
(0.013)\end{array}$ & $\begin{array}{l}1.035^{* * *} \\
(0.013)\end{array}$ & $\begin{array}{l}1.034^{* * *} \\
(0.013)\end{array}$ \\
\hline $\begin{array}{l}\text { FX rate } \\
\text { (LCU per weighted avg) }\end{array}$ & $\begin{array}{l}-0.002^{* * *} \\
(0.0004)\end{array}$ & $\begin{array}{c}-0.002^{* * *} \\
(0.0004)\end{array}$ & $\begin{array}{c}-0.002^{* * *} \\
(0.0004)\end{array}$ & $\begin{array}{l}-0.002^{* * *} \\
(0.0004)\end{array}$ \\
\hline $\begin{array}{l}\text { FDI inflows (billions of } \\
\text { USD) }\end{array}$ & $\begin{array}{l}0.001^{* * *} \\
(0.0002)\end{array}$ & $\begin{array}{l}0.001^{* * *} \\
(0.0002)\end{array}$ & $\begin{array}{l}0.001^{* * *} \\
(0.0002)\end{array}$ & $\begin{array}{l}0.001^{* * *} \\
(0.0002)\end{array}$ \\
\hline OECD & & $\begin{array}{c}0.014 \\
(0.064)\end{array}$ & & $\begin{array}{c}0.014 \\
(0.064) \\
\end{array}$ \\
\hline Observations & 1,718 & 1,718 & 1,718 & 1,718 \\
\hline $\mathrm{R}^{2}$ & 0.826 & 0.826 & 0.826 & 0.826 \\
\hline Adjusted $\mathrm{R}^{2}$ & 0.816 & 0.816 & 0.816 & 0.816 \\
\hline F statistic & $\begin{array}{c}1,925.245^{* * *} \\
(\mathrm{df}=4 ; 1,622)\end{array}$ & $\begin{array}{c}1,539.301^{* * *} \\
(\mathrm{df}=5 ; 1,621)\end{array}$ & $\begin{array}{c}1,539.504^{* * *} \\
(\mathrm{df}=5 ; 1,621)\end{array}$ & $\begin{array}{c}1,282.174^{* * *} \\
(\mathrm{df}=6 ; 1,620)\end{array}$ \\
\hline
\end{tabular}

Notes: Models are panel linear regressions with fixed effects specified for country and year. Robust standard errors in parentheses. ${ }^{* *} p<0.05,{ }^{* * *} p<0.01$. LCU, local currency unit.

\section{Appendix 4. Alternative models of WTO accession and yearly imports (1995-2015) - Log dependent variable}

\begin{tabular}{|c|c|c|c|c|c|c|}
\hline & \multicolumn{6}{|c|}{ Dependent variable: } \\
\hline & \multicolumn{4}{|c|}{ Services imports (Log millions of USD) } & \multicolumn{2}{|c|}{ Goods imports (Log millions of USD) } \\
\hline & (1) & $(2)$ & (3) & (4) & $(5)$ & $(6)$ \\
\hline Rigorous accession to the WTO & $\begin{array}{c}0.027 \\
(0.036)\end{array}$ & & & & $\begin{array}{l}0.076^{* * *} \\
(0.026)\end{array}$ & \\
\hline Accession rounds of questioning & & $\begin{array}{c}0.002 \\
(0.004)\end{array}$ & & & & $\begin{array}{l}0.007^{* * *} \\
(0.002)\end{array}$ \\
\hline Services commitments general & & & $\begin{array}{c}0.002 \\
(0.004)\end{array}$ & & & \\
\hline Services commitments specific & & & & $\begin{array}{c}0.0002 \\
(0.0004)\end{array}$ & & \\
\hline Log GDP (billions of USD) & $\begin{array}{l}1.039^{* * *} \\
(0.013)\end{array}$ & $\begin{array}{l}1.040^{* * *} \\
(0.013)\end{array}$ & $\begin{array}{l}1.041^{* * *} \\
(0.013)\end{array}$ & $\begin{array}{l}1.041^{* * *} \\
(0.013)\end{array}$ & $\begin{array}{l}1.122^{* * *} \\
(0.009)\end{array}$ & $\begin{array}{l}1.124^{* * *} \\
(0.009)\end{array}$ \\
\hline FX rate (LCU per weighted avg) & $\begin{array}{c}-0.002^{* *} \\
(0.0004)\end{array}$ & $\begin{array}{c}-0.002^{* *} \\
(0.0004)\end{array}$ & $\begin{array}{c}-0.002^{* *} \\
(0.0004)\end{array}$ & $\begin{array}{c}-0.002^{* *} \\
(0.0004)\end{array}$ & $\begin{array}{c}-0.004^{* * *} \\
(0.0003)\end{array}$ & $\begin{array}{c}-0.004^{* * *} \\
(0.0003)\end{array}$ \\
\hline FDI inflows (billions of USD) & $\begin{array}{c}0.001^{* * *} \\
(0.0002)\end{array}$ & $\begin{array}{c}0.001^{* * *} \\
(0.0002)\end{array}$ & $\begin{array}{c}0.001^{* * *} \\
(0.0002)\end{array}$ & $\begin{array}{c}0.001^{* * *} \\
(0.0002)\end{array}$ & $\begin{array}{c}0.001^{* * *} \\
(0.0001)\end{array}$ & $\begin{array}{c}0.001^{* * *} \\
(0.0002)\end{array}$ \\
\hline $\begin{array}{l}\text { Observations } \\
\mathrm{R}^{2}\end{array}$ & $\begin{array}{l}1,718 \\
0.826\end{array}$ & $\begin{array}{l}1,718 \\
0.826\end{array}$ & $\begin{array}{l}1,718 \\
0.826\end{array}$ & $\begin{array}{l}1,718 \\
0.826\end{array}$ & $\begin{array}{l}1,718 \\
0.918\end{array}$ & $\begin{array}{l}1,718 \\
0.918\end{array}$ \\
\hline Adjusted $\mathrm{R}^{2}$ & 0.816 & 0.816 & 0.816 & 0.816 & 0.913 & 0.913 \\
\hline F statistic $(\mathrm{df}=4 ; 1,622)$ & $1,921.470^{* * *}$ & $1,921.249^{* * *}$ & $1,920.856^{* * *}$ & $1,920.909^{* * *}$ & $4,534.429^{* * *}$ & $4,534.439^{* * *}$ \\
\hline
\end{tabular}

Notes: Models are panel linear regressions with fixed effects specified for country and year. Robust standard errors in parentheses. ${ }^{*} p<0.1,{ }^{* *} p<$ $0.05,{ }^{* * *} p<0.01$. 